\title{
Comparative Study of Civil Procedure in Common Law and Civil Law Systems
}

\author{
Nader Ghanbari ${ }^{1}$, Hassan Mohseni ${ }^{1,2} \&$ Dawood Nassiran ${ }^{1}$ \\ ${ }^{1}$ Department of Law, Najafabad Branch, Islamic Azad University, Najafabad, Iran \\ ${ }^{2}$ Department of Law, Tehran University, Tehran, Iran \\ Correspondence: Hassan Mohseni, Department of Law, Najafabad Branch, Islamic Azad University, Najafabad, \\ Iran.
}

Received: May 28, 2016 Accepted: June 17, 2016 Online Published: June 29, 2016

doi:10.5539/jpl.v9n5p267 URL: http://dx.doi.org/10.5539/jpl.v9n5p267

\begin{abstract}
Comparing the legal systems is a specific method in which due to its important function is considered as a separate branch in law. None of the branches in law can place its knowledge merely on ideas and findings within the national borders. Several basic objections have been given regarding the definition and purpose of comparative study in civil procedure. In addition there are specific problems regarding studying practically the similar systems in a legal system like differences in purpose, definition and concept. In different legal systems like civil law and common law systems in which there is a divergence, even the judicial system 's organs and judges` appointment and judicial formalism are different, which add to the problems of the comparative study. Reviewing these differences could lead to a better understanding of these legal systems and recognizing the common principles in making use of each other's findings considering these differences and indicate the obstacles of comparative study in this regard.
\end{abstract}

Keywords: civil procedure, comparative study, civil law, common law

\section{Introduction}

Comparative law not only leads to a better recognition of the foreign laws, but also it is consistent with commerce universalization and law unification. Law is not merely the knowledge to interpret the national laws; it rather can provide a wide range of problem solving models whichcould work in solving the national affairs and these models exist within the national borders of the developed countries.

The most modern codes or most of the reforms ${ }^{1}$ are the results of comparative studies even if the legislator does not specify the sources of these modifying ideas and even if this is not correct that most adoptions are the result of the comprehensive comparative studies, it can be understood that these modifications according to the political pressures or influences are rare.

Although some researchers claim that procedural law is not based upon the comparative studies but there is no difference between civil procedure and other branches of law. They claim that procedural principles represent to predicate on specific rules, namely the Loipolitiqueswhich is not capable of transferring to other countries and societies. $^{2}$

In fact, recent historical narrations and experimental evidences both reveal that the national legal systems are systematically in accordance with legal traditions or roots in which their countries belong. Specifically procedural and substantive codes in civil law countries differ systematically with common law rules. A wide range of scientific findings as supporting the legal roots theories reveals that legal roots considerably form the society`s characteristic structure including the relationship between state and individuals, therefore it affects the

\footnotetext{
1- Regarding the comparative civil procedure in the United States of America it has been stated that the comparative civil procedure doesn't have a significant role in the academies, legislation and judicial opinions. There are several reasons like American exceptionalism. It refers to this fact that however there are wide differences between common law and civil law systems on civil procedure, this branch in the united states is even far more different from its counterparts in common law systems. This American exceptionalism is a major obstacle towards the benefits of comparative study and reforms in civil procedure.

Scott Dodson, comparative convergences in pleading standards, 2009, p. 1

${ }^{2}$ - Peter Gottwald, Comparative civil procedure, 2004, pp. 1,2
} 
codes, procedures and other rules and a wide range of economic outcomes follows. ${ }^{3}$

According to this theory, using the civil procedural law models is a misuse of comparative law and has to end in disappointment. If so, civil procedure will merely be a branch of law which is not capable of using the comparative studies. As 12 universal procedure congresses has been held since 1950 which covers almost all essential issues and difficulties in procedure, so we could claim that the opposite viewpoint is correct.

\section{The Purpose of Procedure}

The main purpose of the civil procedure is to specify the rights and obligations among individuals in accordance with law. Determining the parties' rights and obligations to settle the disputes. In case there is no procedure, the individual might make use of their power in order to realize their rights and settle their disputes and consequently a more powerful result than justice will dominate. ${ }^{4}$

In fact, the civil procedure functions as the leverage of justice in settling private disputes in the society. The civil procedure obstructs misuse of power in resolving the legal issues ${ }^{5}$ and prevents indulgence in legal affairs ${ }^{6}$ and also results in maintaining justice in the society and consequently efflorescence in capacities, society`s development and cultural growth, a wide range of productivity in the facilities, reduction in violence and tension, hope to employment and endeavor and future through establishing unified laws which all individuals are equal.

\section{The Definition of Civil Procedure}

Civil procedure is defined as a set of legal rules governing the civil courts` organization and function which is competent to settle the disputes that are affected by the private benefits. ${ }^{8}$

The civil procedure is a process to apply the laws to the facts in order to settle the disputes. The purpose of civil procedure is to facilitate decision making according to the law and consequently practical implementation of legal reasoning. Lawsuits commence the courts' trials, the trials proceed and finally the issued verdicts are the result of lawsuits. Of course the sole role of trial is not to reach the precise results. Rather we expect some from the exact proceedings. We expect the proceeding to be fair, fast and efficient.

The basic commitments of civil procedure which are best realized are as follows: exactly determining the right through fair trial process, proceedings without delay, free availability to all, and being precise, fair, fast and efficient. In fact it seems that the civil procedure functions in order to support the individuals private rights in the world and the rules are codified in order to adjudicate the individuals' private rights.

Therefore, this question arises that isn't it better to address the judicial private law rather than civil procedure? This is an appropriate question since we encounter both terms in French law which could be problematic to an unfamiliar reader. The traditional term in this regard is civil procedure. This tradition dates back to Louis IIV reign and considering the civil procedure code in April 1667 concerning "the reform of justice", the first interpreters in this context used the term civil procedure. According to the civil procedure ode 1806, Napoleon code, training civil procedure was nothing more than instructing law. This titlewasn't problematic till the end of $19^{\text {th }}$ century, in this century the procedural rules and administration techniques were added to the college courses regarding studying the judicial organization and it seemed that the term civil procedure was far more restricted and therefore incorrect. Thus, like some foreign writers, especially Italian researchers, some experts tend to address to "the judicial private law" in the beginning of $1940 .{ }^{9}$ Therefore the judicial private law means both the civil justice law (judicial organization and courts` competences) and civil procedural law. (Lawsuits in court, proceedings, revisal and administration techniques). ${ }^{10}$

\footnotetext{
3 - AronBalas, Ratael La porta, Florencio Lopes-de-Silanes, Andrei Shleiter, the divergence ot legal procedures, 27 July 2007 , p. 2

${ }^{4}$ - James R. Maxeiner, pleading and Access to civil procedure: Historical and comparative reflections on Iqbol, A day in court and decision according to law, 26 March 2010

5- Section 9 articles 3 of the constitutional law, section 1 of article 3 , article 34 and ... and articles 1,2 , and $8 \ldots$ of civil procedure code

${ }^{6}$ - section 6 article 51, 63, sections 2, 6 of article 81, article 132, 141, 275, 362, section 2 article 436 ... of civil procedural code.

${ }^{7}$ - However, the prerequisite of equality between individuals are a fair civil procedure and fair implementation by judges. And perhaps that's why napoleon code in France inflicted and absolute procedural formalism on the courts proceedings in order to eliminate judicial prejudice in France.

Ross Levine, Law, Endowments, and property rights, p. 3

${ }^{8}$ - Loiccadiet, Introduction to French ciril justice system and civil procedural law, last visited september 2010

James R. Maxeiner, pleading and Access to civil procedure: Historical and comparative reflections on Iqbol, A day in court and decision according to law, 26 March 2010

9 - droitludiciaireprive

${ }^{10}$ - Loiccadiet, Introduction to French civil justice system and civil procedural law, p. 332
} 
In this paper we follow the common method in books and internal and foreign articles and use the term civil procedure.

\section{The Concept of Civil Procedure}

While studying the civil procedure rules it is certain that like other laws, civil procedure is capable of being considered as a set of expedients in order to affect, punish, compensate and powerfully clarify the human's acts. Trial is often defined as a game. The parties to the litigation are like players and judges are like referees. This game is ruthlessly competitive and it is often presumed that it has winner and loser. Realizing its rules like some games is abstractly difficult. These regulations are live and might be meaningful through experience and being played. Consequently, our understanding fromcivillitigation will be much easier than civil procedure.

The litigations are different from most games. Firstly, most games are done in order to amuse the audience or participants and while they are rather innocuous, it isn't hard to justify. On the contrary, litigation includes a heavy burden of reasoning. This game can inflict cumbersome expenses ${ }^{11}$ on the parties, court and public and often has a single enthusiastic player: plaintiff.

Thus, civil procedure cases and the problems regarding ought to be considered from expense control or resources designation perspective. If the dispute between the parties resolves anyhow, will the need to civil procedure be needed? Is the specific tactics is needed by the parties to the litigation as the legal procedural instruments in order to achieve the essential aims, or there's no need to these unreasonable and somewhat burdensome which are inappropriate towards aims? Which factors ought to establish a balance between judicial control and independence of parties to the litigation? ${ }^{12}$

The lord chancellor of House of Lords, appointed Lord Woolf ${ }^{13}$ in 1994 in order to review the civil procedure to improve the achievement to justice, reduce the litigation expenses and eliminate unnecessary complications. He argued that we need to find the reason of these high expenses in motivations which force the lawyers to make the proceedings complicated not the civil procedure complications.

When we study the concept of civil procedure from national point of view, we don't face major problems. In principle, civil procedure applies on the legal proceedings of courts to civil cases. Some incident problems exist in this regard though, for instance in some countries like France and Holland there is a restricted unit for decision making regarding civil claims towards indemnity in penal procedure. On the other hand, while jurists and lawyers are completely ready to give a definition on civil procedure at the national level, this is totally different in comparative law researches. In this regard one can argue that civil procedure is the applicable law to civil cases in courts. Yet, if one considers this definition carefully, he can conclude that it is problematic.

The first difficulty is giving a definition on the civil case (yet this won't be surprising towards the ones who are familiar with judicial precedents of European court of human rights on the definition of civil law and obligations in the article 6 of the European convention of human rights).

For instance, in England, "civil" adjective is used in both civil and penal branches. But in most civil law states, the divergence exists between two main branches, i.e. public and private law. The procedural rules towards claims within public law are either penal or administrative. Administrative procedure rules are applicable to the cases in which one of the parties is the government or other public authorities. Consequently, civil law has a main difference comparing to jurisdictions like England, which is where the cases against the government are being adjudicated according to customary civil procedural rules.

The second difficulty on defining the civil procedure regards to classifying the laws to procedural and substantive. This classification is of essential importance at the international level in order to realize the capability to implement lexfori regarding the procedural law.

Although courts are able to apply the foreign substantive law, but the national courts cannot decide according to foreign rules of civil procedure. It seems that we'd better clarify the differences between substantive and procedural law initially. The substantive law refers to the rules and regulations which adjust and beget rights and

\footnotetext{
${ }^{11}$ - The suggestions on collusion and reconciliation aim to faster settling the disputes and reducing the legal expenses of litigations. Therefore, suggestions are provided in most pleas considering the given economic formulas in order to dispute settlements. The suggestions on dispute settlement in common law specifically the jurisdictions which follow English legal system, are highly accepted while the suggestions on dispute settlements in civil law are unknown.

Pablocortes, An analysis of offers to settle in common law courts: Are they relevant in the civil law context?

${ }^{12}$ - Chapter 1, Introduction, what is civil procedure, pp. 1, 4.

${ }^{13}$ - A. A. S. Zuckerman, LORD WOOLF'S ACCESS TO JUSTICE: PLUS ÇA CHANGE ...,p. 1
} 
obligations, while the procedural law regulates the civil proceedings regarding the disputes related to these substantive rights and obligations. Yet, these differences are not always clear. For instance, how can we classify the remedies in England legal systems? Do they belong to procedural or substantive law? ${ }^{14}$

In some jurisdictions like France, the proofs of evidence are found both in civil law and civil procedural law. In Holland there was initially a legal system like France which had a upturn and the proofs of evidence transferred to civil procedure law.

According to the above findings, it is concluded that the definition of civil procedure in comparative law is difficult. However, if one is going to define the civil procedure, it seems that the precise definition by J.A Jolowicz is acceptable. He argues that: 1) the civil procedure includes the procedure techniques in courts. 2) The litigation onset is a voluntary act. 3) the plaintiff's acts are in order to gain benefits. 4) Civil procedure won't happen without having a defendant.

This definition indicates some kind of litigation in which the civil procedure is being controlled. However this definition is helpful in legal comparative studies, but the mentioned definition is not ideal for some sections which are not referred to as the civil procedure in some countries.

Complicated areas like rules governing the judicial organization, implementation, are rules concerning issues which don't include litigation adjudication, rather are administrative. (For instance appointing a guardian) ${ }^{15}$

The advantages of studying the comparative civil procedure

The comparative study of civil procedure like other branches of law provides benefits and advantages that are being used in comparative studies overall. The comparative studies contain scientific, revisory and social benefits. Scientifically, procedural traditions and other countries' procedural regulations could deepen one's understanding of the procedural norms ${ }^{16}$ and stop the acts otherwise ${ }^{17}$. On the other hand the comparative studies could develop the individual's knowledge and mind and help as a means to describe and establish an analytic framework (in civil procedure) towards finding the fundamental principles of litigation ${ }^{18}$.

The fundamental principles of civil procedure which has been indicated in some comparative studies were the result of comparative studies. In this regard it has been argued that we ought to presume a differencebetween the fundamental principles and other principles in civil procedure.

The fundamental principles of civil procedure could be considered as standards in order to fully realization of justice. When these principles are being ignored, we cannot address the fair trial. Some of the principles are not fundamental, yet are being respected in some jurisdictions, but if they are being ignored, the fairness of trial won't be at risk ${ }^{19}$.

\footnotetext{
${ }^{14}$ - article 6(1) of the European convention of human rights provides:

"In determining the civil rights and obligations of an individual or any penal accusation against him, one is entitled to a fair and public trial at a reasonable time through a fair and independent out of law."

In the commentary provided of this article it is stated that this section guarantees five issues:

A- Access to justice (this guarantee is not mentioned in article 6(1) but implied by the European court of human rights)

B- Fair trial, including:

1- The right to attend in a litigation

2- Equality of arms

3- providing the evidences fairly

4- the right to counter review (evidences)

5- $\quad$ open proceedings, including declaring the verdict in public

6- $\quad$ holding the sessions at a reasonable time

7- $\quad$ Litigation in an independent and neutral court which is pitched by law.

Neil ANDREWS, English Civil Procedure: A Synopsis JAPAN COURSE 2006,pp. 5,6

${ }^{15}$ - Prof. Dr. G.H. van Rhee, professor of law, Maastricht University \& Mr. R.Verkerk, researcher, Maastricht University civil procedure, 2006, pp. 1,2

16 - the author has studied the procedure in the united states of America, therefore in the main text the term "U.S procedural" has been used; but this scientific benefit does not merely dedicate to the comparative study of the united states system. Thus, considering the non-assignment of this term, it has been eliminated.

${ }^{17}$ - Scott Dodson, comparative convergences in pleading standards, 2001, p. 2

${ }^{18}$ - PetterGottwald, comparative civil procedure, 2004, p. 2.

19- Prof. Dr. G.H. van Rhee, professor of law, Maastricht University \& Mr. R.Verkerk, researcher, Maastricht University civil procedure, 2006, p. 4.
} 
Finding the fundamental principles of litigation could result in the correct understanding of our laws and sometimes help us towards improving or defending our current situation or the reasons to it.

Scientifically, the increasing prevalence of judicial cases and transnational bargains rose widespread needs concerning reviewing the foreign laws and procedural techniques ${ }^{20}$. These needs are significantly important considering this fact that the international trade has been developed in recent decades and is no longer affected by the developed countries.

The international commerce rules are currently determined by countries with different levels of economic and legal development which leads to a completely different legal framework for international transaction. The variety in concepts, techniques and legal methods among legal systems reflected on the applicable rules in international transactions. This difference in legal systems amounts to obstacles in international commerce and often results in problems in the process of ratifying and implementing the international transactions. In addition, since the judges are instructed within the national systems, therefore they are often totally unfamiliar with the concepts and expressions between the national legal system and the foreign ones ${ }^{21}$.

In this regard, the comparative studies could serve as a method in order to transnational unity or law harmonization, specifically through the model laws ${ }^{22}$.

In addition the comparative studies provides an opportunity to think and modify the national laws for individual systems, through learning and realizing other legal systems, either by means of imports or exports, in order to provide a different method to solve the common issues. ${ }^{23}$

Howeverborrowing from foreign countries isn't necessarily the result of complete comparative studies. When Professor Maurer appointed to codify the Greek civil procedural law by King Otto in 1834, he incorporated the French and German ideas and processed the draft articles out of his knowledge from French and German law. But he did not perform a real comparative project.

When the Japanese government decided to adopt the German civil procedural code 1877 in 1889 , it was hard to accept that a thorough comparative analysis with the chief laws has been performed, rather they merely intended to adopt a modern model and at that time German was politically and economically successful. After World War II American lawyers insisted on adopting some of the civil procedural models in common law. It doesn't seem like this accession has been done after a thorough comparative analysis.

Finallyborrowing from foreign countries must get done in an appropriate time in order to transform to a successful start. $^{24}$

The specific problems of comparative study of the civil procedure

Irrespective of the general problems ${ }^{25}$ regarding the comparative studies, we encounter specific difficulties regarding the comparative study of civil procedure whichis mentioned below:

A) the lexfori principle

In order to solve a transnational issue under the substantive law, regulations on conflict of laws are being used. Regarding the civil procedure, the courts exclusively apply the national procedural law, and don't consider the procedures of foreign governments or rules which are being served in practice or through judicial precedent.

The national procedural rules which refer to the foreign laws, mainly concern the conditions of recognizing the foreign verdicts, timely and correctservice. Therefore the comparative study on civil procedure concentrated on questions like competence and recognizing and implementing the foreign verdicts for a long time. Of course there was a limited area which mainly contains the academic studies or those studies have been done with the

\footnotetext{
${ }^{20}$ - peter Gottwald, Comprativecovil procedure, 2004, p. 2

${ }^{21}$ - for example, in civil law legal systems the initial solution to redress is specific performance, while in the common law system, the initial solution is to claim damages and merely under the equanimity, courts issue the verdicts in favor of specific performance.

GussiKoskinen, specific performance in GISG and Finish law, electronic library on in transactional commercial contracts and the GISG, www.cisglaw.pace.edu, 1999, page number 8, last visited 2010,11, p. 8

${ }^{22}$ - Like the principles of transnational procedures.

${ }^{23}$ - Scott Dodson, comparative convergences in pleading standards, 2001, p. 2

24- PetterGottwald, general functions and aims of comparative law, 2004, pp. 2,3.

${ }^{25}$ - difficulties like comparing the legal cultures, fundamental analysis of collected data, comparing living law (i.e. in order to understand the laws and evaluate the relationship for solving specific problems, sometimes sociological studies or practical information are needed. Therefore the comparative law is closely related to legal sociology. For instance the legal rules and regulations on the access to the evidence through witnesses. These rules could be seducer, unless we know that if preparing the witness by the lawyers is practically common or not)
} 
aim of law modification.

\section{B) Forum shopping}

In the past years, the foreign procedure has been concerned with forum shopping even for lawyers. When we encounter the abjuration or disagreement in complicated transactions, lawyers wonder that this is a better idea that a claim is mooted in another court, before being filed in a court in the United States, considering the same laws applied by the U.S courts and the privileges of the same procedures. These privileges could be regarding the American law's advantages in which each party incurs its own expenses and on the other hand there are wide facilities for pre-trial discovery, generous evaluation of the incurred damages by the civil jury, alongside with the punitive damages $^{26}$ or making the expenses triple.

C) The heterogeneous act of court

It is agreed in the comparative studies that it is not correct to consider merely the text of modern rules in books; rather the laws must be reviewed in practice. This study could aim successfully through reviewing all decisions specifically the decisions published by the Supreme Court.

When we consider the civil procedure, a different situation is observed. Considering this fact that in the civil procedure the judges are free to ignore the procedural formalities, and are totally dependent on the personal plans, or are forcibly obliged to apply all the absolute rules and formalities, the courts ' practice would be totally heterogeneous. What a local judge in Munich thinks might be different from a judge's point of view in Berlin or Hamburg, or the judges I the same location.Personal viewpoints in a local court would clearly affect the court's judgment, but if this viewpoint does not represent the whole courts in this country, could be misleading in the comparative study: so, a correct comparative study needs a wide study of viewpoints ${ }^{27}$.

The differences of civil procedure in common law and civil law systems

Some jurists consider the civil procedure's dependency on the national power structure and the efficiency of society`s history and culture as an obstacle to use the comparative studies, on the other hand the proponents render the international trade and globalization alongside with the experience of the European court of justice and human knowledge increase and finally achieving the universal common principles in addition to the model civil procedural law using the collective wisdom as the advantages and needs of comparative study on civil procedure.

The historical narrations and recent experimental researches both indicate that the national legal systems are systematically different considering the legal customs and the roots which their countries belong ${ }^{28}$. Specifically the procedural laws and civil law rules are systematically different from common law systems ${ }^{29}$.

The most important difference between civil law and common law systems is that civil law system considers doctrine (including the reports of law drafters) supreme in comparison to the judicial precedent, while it is totally inverse in common law.

such difference in precedence could be indicated by legislator's role in both traditions. The French civil code has accepted the Charles Louis de Secondat Montesquieu`s theory on separation of powers, in which the legislator`s function is to legislate and the court's function is to implement the laws. On the other hand the common law presumes that the judicial precedent out of judges` decisions is the law`s kernel. Common law pays attention to

\footnotetext{
${ }^{26}$ - punitive damages are damages which is paid in order to punish the culprit more than the amount which is necessary for the incurred damage.

Mmktin Elizabeth, oxford dictionary of low, first scan, winter 1383 Tehran, p. 141

While acceptability and credibility of such damages is not considered by the CISG (Vienna convention on the international sale of goods 1980), article 9:5.9 of PECL (principles of European contract law) and article 7.4.13 of UNIDROIT not only contains this title, but also considers a coherent framework in examining such damages. It is generally presumed that punitive damages and other penal sections could be agreed on by the parties to the contracts. In case a specific amount is considered in the contract for non-implementation, this is held irrespective of the real amount of damage which the culprit has incurred. However, in case this amount is highly unreasonable, it could be reduced to a reasonable one.

Friedrich Blas and Philip Hottler, Remarks on the damages provisions in the CISG principles of European contact law (PECL) and UNISROIT principles of International contracts, march 2005, pp. 6, 7.

27 - PetterGottwald, general functions and aims of comparative law, 2004 , page number

${ }^{28}$ - regarding the effects of roman law in civil law systems, it is serious and deep while the common law system is less affected by the roman law in structure and methods.

Arthur T.vonMehran, the U.S. legal system: Between the common law and civil law legal traditions, November 2000, p. 2

${ }^{29}$ - Aronbalas, Rafael laporta, Florencio Lopez - de - silanes, Anderishleifer, the divergence of legal procedures, 27 July 2007, p. 1
} 
the reality of patterns and provides an analysis on the cases ${ }^{30}$.Politically, in the legal history of civil law, law itself is a gift from governor to people. In the constitutional battles in the common law systems, law is regarded as the individuals' birth right against the sovereignty` power. In civil lawthere is a separation between public and private laws. Furthermore, in the private law there is a distinction between the applicable laws on commercial and non-commercial transactions.

On the other hand, the common law is integrated. There is no difference in the applicable law on the relationship between the government and citizens and among citizens with one another. It is treated equally with merchants and other individuals. There is no separate regulation for businessmen.

The most important common law source is the judicial precedent. Lawyers concentrate on the courts' decisions in the concerned jurisdictions or consider other jurisdictions with the comparative aims. However, some regulations are codified in the recent years (for example the uniform commercial code in the U.S.A).

In civil law countries, the first step is that the lawyers review the applicable laws and statutes. In this system the lawyers pay attention to the courts' decisions merely in order to interpret such laws. The statutes provide the law`s kernel in civil law. The general principles have been featured systematically in codex and the specific statutes complete them.

The common law statutes are complemented through judicial precedent which establish the major kernel of the law and are indicated through specific regulations which are applied to specific facts.

Civil law has a tradition of interpreting the statutes and the documents are being interpreted extremely literally in all circumstances. The statutes and judicial documents are concise and it is intended to be written generally and without specific details. On the other hand, the common law statutes provide detailed definitions and each code contains a long set of the specific uses.

Rather, civil law concentrates on the legal principles. Lawyers follow the principles` historical records and analyze their functions.

Both systems are different in their capacity to adjust with the modern situation. Common law is more dynamic since its rules gradually and case by case respond to the society`s changing needs and it is less probable that we witness a large gap between the economic needs and law. On the other hand, the French civil law which is born out of a revolution had a fantasy that could achieve the idealistic aim i.e. creating an unchangeable complete law. However, the French law is adjusted with the commercial realities in practice: Germany has based its framework on Savigny`s vision and seeks to establish a dynamic codex; Spain styled the periodic reforms towards the civil law.

\section{The Common Law and Civil Law Differences in Civil Procedure}

In this section which is the main purpose of writing the article, we study the existing differences in common law and civil law systems concerning the civil procedure. In this regard I shall emphasize that it is tried to provide a list of the existing differences in both systems regarding the procedure which obviously each difference could contain a separate text.

In this article we seek to list the existing differences regarding civil procedure in both systems which is hard to deal with in this article due to the wide range of these differences and on the other hand the manifest ones are described, however the author doesn't argue that this article covered all differences and certainly some of them has been ignored.

\section{The Divergence of Common Law and Civil Law}

The common law's divergence from civil law commenced with the expressions on the judicial organization and the proceeding techniques in England in Henry II reign. Today even the researchers, who have different viewpoints, are unanimous on this fact that there are some difference concerning the judicial instructions and the civil procedure. Specifically the common law jurisdictions intend to centralize the trial, involve the parties to the litigation in a set of evidences, and confine the reconsiderations comparing to the civil law countries. There is a rather standardlist of differences between the American civil procedure and the European style. These differences are often described as the comparative study of common law system (sometimes the Anglo-American system) and civil law. It seems that some of the differences between these two systems are theoretically important, but less important in practice. Common law and civil law countries have currently borrowed from one another somewhat, and their similarities have developed independently, however, there are major differences in the civil

${ }^{30}$ - William Tetley ,q.c,mixed jurisdictions :commonlawv.scivillaw codified andvncoditied):2003 
procedure between the legal traditions of common law and civil law yet. Furthermore, even within the common law system, the American civil procedure has currently separated from the English civil procedure and other common law states in specific paths - especially regarding using the juries, regulations on pre-trial discovery and ...

\section{Judicial System}

Often there are various distinct systems for the courts in civil law countries, while in common law countries it is almost integrated. When one of the courts is competent to decide on a specific legal issue, the othersare not competent to that legal case. While, the common law system could be illustrated in like a pyramid in which the Supreme Court stays on the top. For instance consider the English legal system:

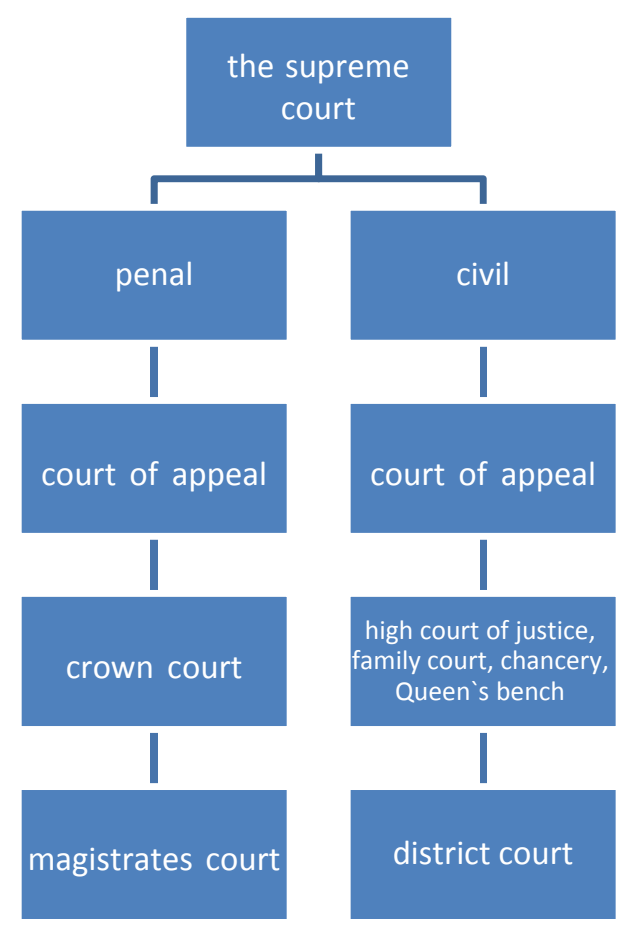

The above chart is a simple version of English courts` system. The appeal committee of the House of Lords that was the final court of appeal for English courts and wales until October 2009, the Supreme Court superseded as the highest court in the United Kingdom.

The court of appeal has appellate competence only, in both civil and penal sections, while the high court of justice and crown court are competent to appellate and original jurisdiction. They decide on the civil and penal cases on the basis of their original jurisdiction, and considering the gravity of the case, decide on the behalf of magistrates' courts.

In the United States of America a simple set of courts (state and federal) decide on both public and private law cases. In the United States at the federal level, there is no technical court to refer to, and only one of the 13 appellate bodies has a technical competence. Among these technical courts, all have the inferior and restricted competence, which in some cases this competence is parallel with the competence of public courts. The most important kind of technical courts in the U.S.A is in fact a governmental system which is a judicial forum, but the decisions made depend on the appellate review in the ordinary courts. The states usually follow the exact same pattern; however there is a wide range of differences between states. The states tend to stay technical (like: penal, entail, family, juvenile, traffic) but almost all of them include the original jurisdiction and the decisions made are being reviewed in the Supreme Court.

The French judicial courts are hierarchically under the supervision of the highest judicial court i.e. the Supreme Court (court de cassation), and on the other hand the administrative courts, under the supervision of the 
governmental council. At the beginning of French revolution, in august 1790 the judicial and administrative functions of the government was separated from the supervision by the judicial courts and rather a specific applied control by the government itself was seated.

In the 1800 and afterwards the courts dualism in French system was established by ratifying a law in 24 may 1872. This code recognized the independence of judicial authorities in governmental councils. Of course the same law established a tribunal for dispute resolution which deals with the conflicts that could arise between two hierarchies of the courts, but this is not the Supreme Court. The mentioned tribunal consisted of equal number of Supreme Court and governmental council members. Therefore, two kinds of courts are common in France: the judicial courts and administrative courts. The civil courts` organization in France is rather simple.

In the first stance, principally the civil courts are competent due to this fact that the courts' competence is general and applies to a wide range of cases like personal status, financial and real state conflicts and verdicts' execution, their local jurisdiction applies to departments in France. A department could have various main civil courts considering the population, the volume of judicial activities and communication network. There are 163 main civil courts in France (for 100 departments). Besides these courts, there are courts with specific competence which deal with the specific cases allocated by the law. Another one is the circuit court that is a substitution to the magistrates' courts and it is competent to deal with the inconsiderable civil claims (like the conflicts between neighbors, the current cases on landleas and cases regarding the debts less than 10,000 pounds).

The commercial courts are the most ancient courts in the French judicial system that their history dates back to the end of Middle Ages. Today there are 135 courts in France. The commercial court is a syndical court which consists of a set of merchants appointed by peers.

The competence of commercial court is beyond the commercial cases, and it is competent to the conflicts between merchants and the conflicts on the commercial activities (like bill of exchange) even if they are not used by the businessmen, and also they deal with the conflicts concerning the commercial companies, and bankruptcy process in commercial and industrial enterprises.

The employment court which dates back to thebeginning of $19^{\text {th }}$ century, settles the personal conflicts arising of the employment, or the employment contractsor internship. The first endeavors in these proceedings are parallel with reconciliation but if the reconciliation did not happen, these conflicts would have been settled through a verdict. There are almost 210 employment courts in France. The members consist of judges, half the employee members and half the employer members.

There are two other courts with technical competences in France which are established by the usual citizens in the mid- $20^{\text {th }}$ century. These courts are as follows: A) the social security tribunals, 116 , regarding the conflicts on social security like participating in a social security plan and paying the stock and shares. B) Mixed courts concerning the rural rents, 305, dealing with the cases on rural rents among landlords and farmers.

Appointment of judges:

Appointment of judges is an important aspect of the judicial independence and the necessary condition for the judges to establish the justice is to be free from any effect or direct or indirect intervention of the sorts. The principle of independence of the judiciary is in accordance with ensuring the judges freedom in fair establishment of justice, without any prejudice or fright. The freedom of judges is closely related to the appointment of judges, because the appointment system has directly affected on impartiality, trust and independence of the judges.

Traditionally common law and civil law follow the different methods of judges' appointment. In the common law countries, the judges in the first instance courts are usually appointed among the practicing lawyers for the specific judicial positions. They are chosen through some legislative acts or by some of executive authorities. The judges of high courts are appointed among practicing lawyers and the judges of the first instance courts, but in both forms, this choice is done through appointment or choosing separately after judge's promotion.

The civil law countries have traditionally a technical system of appointment. Recently, the law graduates are appointed through a process based on eligibility. They are usually needed to pass an exam, but the appointment process also includes reviewing the instruction methods, the instructions afterwards and practical internship. Like other governmental staff, the judges involve in the lower positions and are promoted through increasing their experiences. However, some of the specific countries have been separated from these two models. For instance, in France $20 \%$ of the judges (usually the high level ones) are appointed from the practicing lawyers and professors. 
In the common law system, they tend to appoint the judges among the specialist professional lawyers. Historically, the English judges are appointed by the Lord Chancellor. This appointment was through the competence standards and secret sounding: a unanimous counsel process with indefinite counsel sessions for judges. When an appointed person is a full time judge, the laws prohibit this person from pursuing the personal career. In the practical procedure these staff was almost exclusively appointed through the elderly among the high ranks of lawyers and mostly the law elites. Most people presume that the judiciary acts partially. The judges were merely among the lawyers. Recently a privilege has been granted to the advocates. Solicitors and other legal professionals which has been granted the privilege, worked from the lowest courts and could serve in the highest courts after achieving the personal eligibility.

The reforms in the constitutional law in 2005 in the recent 300 years are the sole fundamental in England. This code allocated the judicial function of the Lord Chancellor to the lord chief justice, who serves as the president of English and wales courts. The principle of the independence of the judiciary has been emphasized repeatedly and the United Kingdom Supreme Court has been established. More importantly this law established an independent jury for judges` appointment and besides assigned an ombudsman to deal with the complaints on the process of judges` appointment. Through the wide counsels on the process of appointment, there is a consensus which will eliminate some of the historical standards of judge's appointment and use the modern employment methods on employing in the judicial positions. In 3 April 2006 this responsibility to employ in most judicial positions transferred to judicial appointments commission which is independent of political support, and functions as a base to appoint the judges merely according to eligibility. In the United States of Americasome of the state judges are chosen by the voters. They can spend their financial aids in the election process like politicians. Regarding the process of judges` appointment in the United States of America it is necessary to take a brief look at the judicial structure of the United States. The judicial structure in the United States is recognized as a dual system. i.e. states and federal have separate set of courts. Therefore there are 51 courts in the United States which are separate, and there is a set for each state and a set for the federal government: the Supreme Court, circuit court of appeals and district justice. This chart illustrates the federal courts in the United States of America.

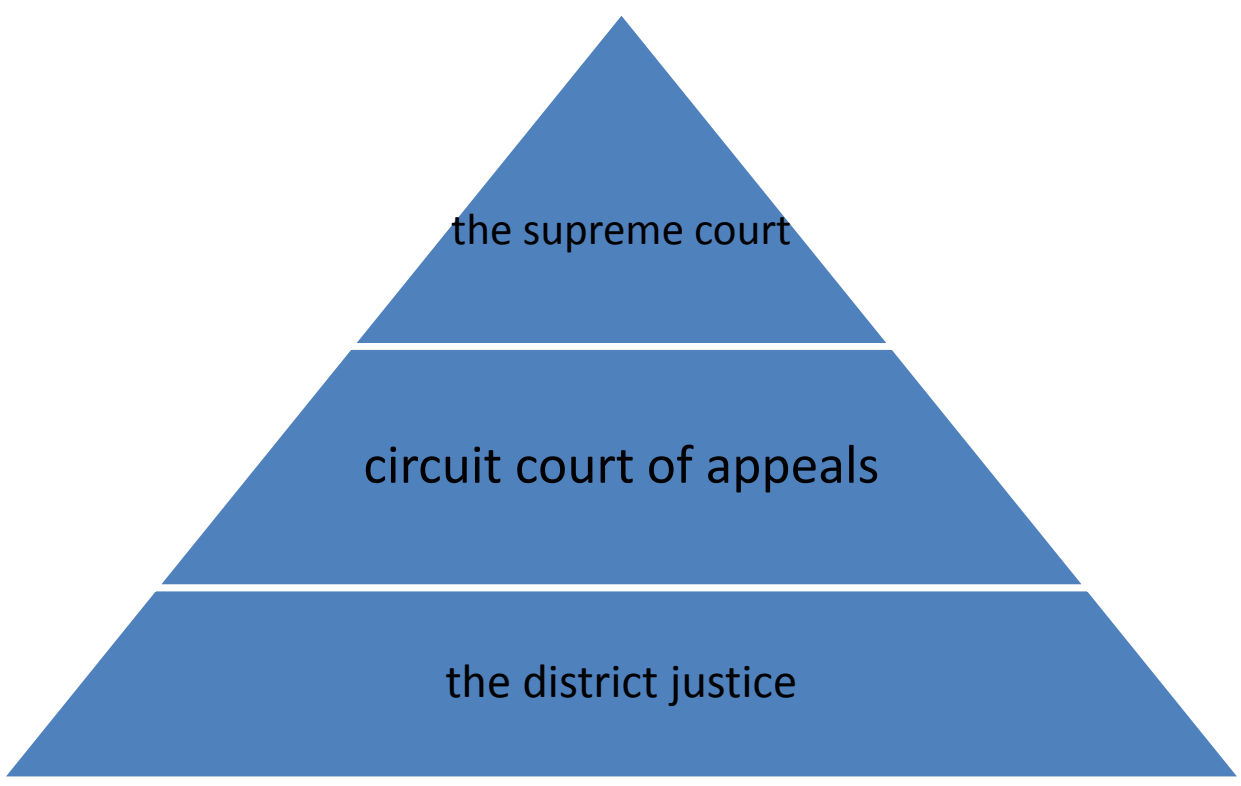

\begin{tabular}{lll}
\hline Competences & The number of judges & The number of courts \\
\hline $\begin{array}{l}\text { Appellate from federal or state } \\
\text { courts }\end{array}$ & $\begin{array}{l}\text { The chief of Supreme Court } \\
\text { Appellate from the district courts }\end{array}$ & The Supreme Court \\
$\begin{array}{l}\text { established in the same jurisdiction } \\
\begin{array}{l}\text { Dealing with the federal cases } \\
\text { including penal or civil }\end{array}\end{array}$ & $\begin{array}{l}\text { Court of appeal } \\
\text { nastrict justice }\end{array}$ \\
\hline
\end{tabular}


The supreme court judges, the courts of appeal judges and district justices are appointed by the united states president and senate's counsel and approval. These judges are appointed lifelong and could be dismissed through congress. This process begins when a judicial position is being held vacant. This vacancy could be due to decease, resignation and being retired. On the other hand, this vacancy could be as the result of a setting new judicial position or indication by the congress. The process of judges ' appointment is illustrated briefly in the chart below. The process of judges 'instruction after the appointment is illustrated in the next chartcomparatively.

The appointment process of federal judges in the U.S.A

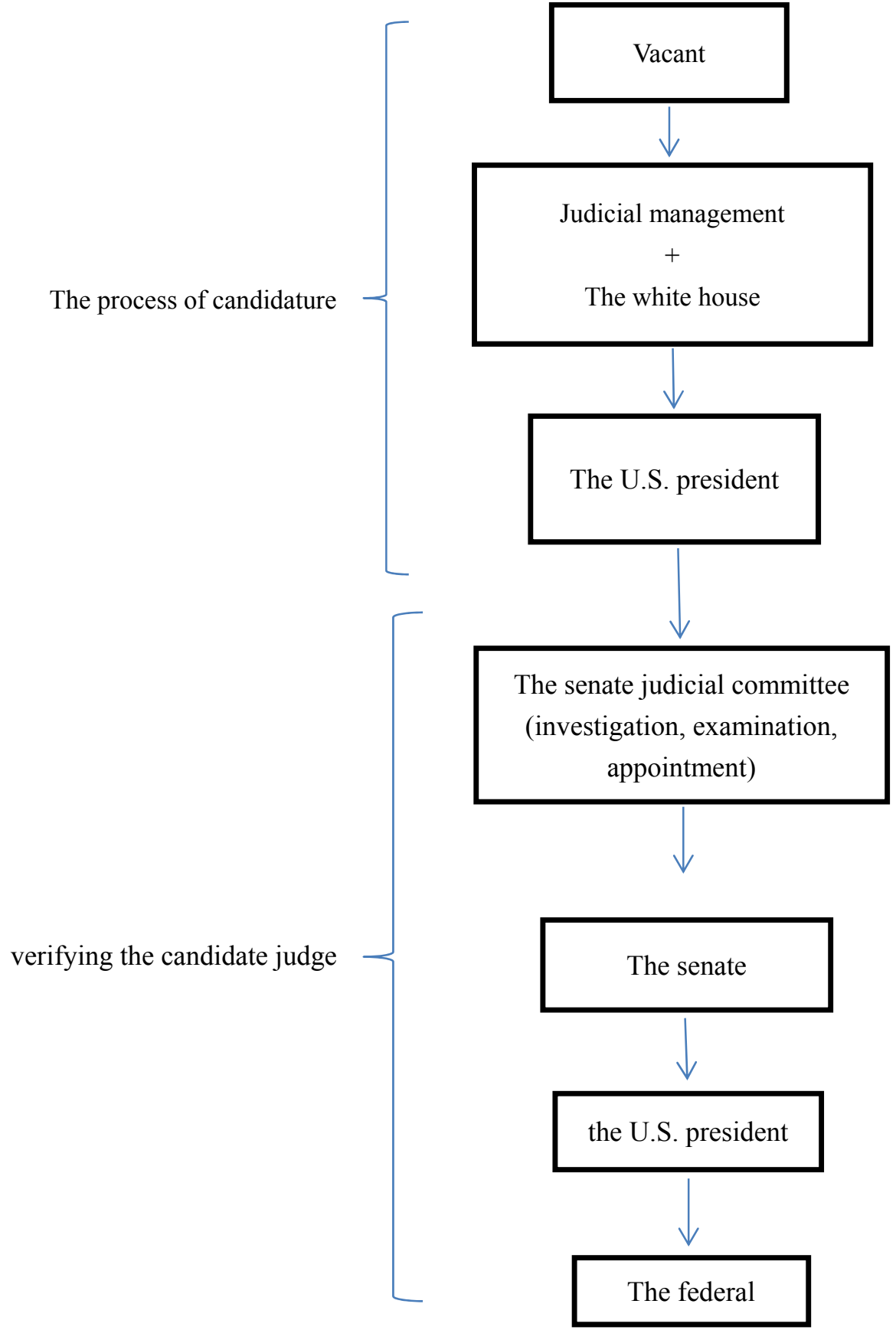




\begin{tabular}{|c|c|c|c|c|c|}
\hline country & $\begin{array}{l}\text { The organization providing } \\
\text { the instruction }\end{array}$ & The instruction body & domain & $\begin{array}{l}\text { Obligatory or } \\
\text { voluntary }\end{array}$ & $\begin{array}{l}\text { People entitled to } \\
\text { the instruction }\end{array}$ \\
\hline australia & justiceministry department & $\begin{array}{l}\text { The investigation judges and } \\
\text { prosecutors in the instruction } \\
\text { department }\end{array}$ & $\begin{array}{l}\text { Judges } \\
\text { prosecutor }\end{array}$ & Voluntary & $\begin{array}{l}\text { Judges } 3-4 \text { days } \\
\text { per year }\end{array}$ \\
\hline canada & affiliationuniversity & Nationaljudicialinstitue & judges & Voluntary & $\begin{array}{l}\text { For the new judges } \\
10-15 \text { days per } \\
\text { year for } 4 \text { years }\end{array}$ \\
\hline spain & State judicialSchool & Law faculty & judges & Voluntary & \\
\hline france & State judicial School & The judicial national school & $\begin{array}{l}\text { Judges and } \\
\text { prosecutors }\end{array}$ & $\begin{array}{l}\text { Voluntary } \\
\text { In the higher } \\
\text { positions } \\
\text { obligatory }\end{array}$ & $\begin{array}{l}\text { All the judges are } \\
\text { entitled to } 5 \text { days } \\
\text { per year }\end{array}$ \\
\hline finland & Justiceministry department & $\begin{array}{l}\text { Department of judicial } \\
\text { Administration }\end{array}$ & judges & Voluntary & \\
\hline germany & State judicialschool & The procedure institute & $\begin{array}{l}\text { Judges and } \\
\text { prosecutors }\end{array}$ & Voluntary & \\
\hline italy & $\begin{array}{l}\text { New state judicial } \\
\text { school }\end{array}$ & $\begin{array}{l}\text { Superior commission of counsel in } \\
\text { the judiciary }\end{array}$ & $\begin{array}{l}\text { The } \\
\text { instruction } \\
\text { commission }\end{array}$ & $\begin{array}{l}\text { Judges and } \\
\text { prosecutors }\end{array}$ & Voluntary \\
\hline $\begin{array}{l}\text { The } \\
\text { united } \\
\text { states of } \\
\text { america }\end{array}$ & affiliationuniversity & $\begin{array}{l}\text { National judicialcollege } \\
\text { Federal judicial center } \\
\text { national center for state courts }\end{array}$ & $\begin{array}{l}\text { Judges } \\
\text { staff }\end{array}$ & $\begin{array}{l}\text { Voluntary } \\
\text { federal } \\
\text { Obligatory } \\
\text { states }\end{array}$ & $\begin{array}{l}\text { It is different in } \\
\text { each state: } 7 \text { to } 15 \\
\text { hours per year }\end{array}$ \\
\hline
\end{tabular}

\section{The Role of Judges}

There are two main systems for proceeding: adversarial and inquisitorial. The common law procedure method is adversarial. In this legal system the lawyer control the methods of providing the evidences and inquiry the witnesses. The lawyers represent their clients' position in the case. The judges act as the impartial juror who are not familiar with the facts of the case before the proceedings and could decide toeitheraccept the evidences or refuse.

On the contrary, civil law method is rather based upon the inquisition. The judge is more active than the common law judges. He is responsible to interrogate the parties and the witnesses, but is prohibited to impregnate the witnesses according to the facts other than what they are called upon. The judge can specify the expert witnesses before the hearing.

However, in describing the differences between the two legal systems on civil procedure, these two terms are not satisfying enough and we'd better make use of the concept "parties' control", i.e. in the common law the parties to the litigation control the proceedings including the discovering and providing the evidences, and the judges' acts are like a passive juror who executes the applicable Laws on the proceeding and proofs of evidence, however he could be supplementary to evidence discovery. However it does not mean that the civil law cases are not adversarial because the parties (and their solicitors) are certainly opponent at least in definition. Therefore these differences are emphasizing all over the systems. In civil law systems the judge in the first instance courts functions as to investigate the facts of the case including the witnesses and documents and allows the supplementary questions from the witnesses. On the contrary, in the adversarial system the parties and their 
lawyers are held responsible to discover and provide the evidences and witnesses who naturally it isn't expected to stay impartial.

The initial role of the judges is to control the provided evidences to adjust with the rules on proofs of evidence and generally providing a suitable opportunity to both sides in order to provide evidences on their claims.

The most important aspect of adversarial system is that it is not prohibited to investigate the other party's witness and also resort to blemish the provided evidence by the other party in order to invalidate them. The judge could question the witnesses or order to provide the documents but he rarely uses this option.

In the adversarial system the onus of providing the evidence is closely related to other aspects including the use of jury in hearings, proofs of evidence and pre-trial discovery.

Judicial formalism

The main issue in the economics is that the security of properties and implementing the contracts in order to investment, commerce and finally development is essential.

Most of the legal institutions serve the security of properties and implementing the contracts. Some of them are totally private, like the informal debates between neighbors which is done without the intervention of the sovereignty and others are like legislators and governmental courts. The courts settle the conflicts concerning the contracts and properties. The economic theories don't argue that this mechanism of settlement is the best one, and in fact is complete. Executing the private security often leads to violence however it works well in some environments. From Smith's viewpoint the acceptable management in this regard, is adjudicating as one of the government's functions in order to enable a normal citizen to demand the adjudication against a wealthy person. Because most of the wealthy offenders are people who hold the private control of implementation.

An experimental study on the courts' effects as the mechanisms of dispute settlement in simple conflicts has been done in 109 countries and it has been reviewed that how the plaintiff could petition in a formal forum regarding a demand to eject the tenant who does not pay his dues or a set of bounced check: they found out in this study that even in these simple disputes the settlement has been done really slowly in the courts and on average it has longed more than 200 days. In addition, it has been found out that there is a wide range of rules regarding the courts' speed and quality. In a theoretical model of an ideal court, a conflict between two neighbors could be settled by a third party with fairness, and through less knowledge, without the presence of lawyers, and any written notification, and without procedural commitments on the evidences, witnesses, how to provide the reasoning and without any appeal.

But in fact, all the legal systems have regulated a heavy process to settle their disputes. They depend on the professional lawyers and judges, have formulated many steps for the conflicts to cover, collecting and providing the witnesses, legal justifications on the need to provide plea and insist on the judges to make decisions, prefer the written bills ... do these formalities suffice to settle a simple dispute?

The researches in the comparative law indicate that systematically there is a different formalism among the legal roots. Specifically the civil law countries formulate the process of dispute settlement by judges and perform this task more than other common law countries.

The German jurist Rudolf vongherine argues that: "the civil procedure is opposite the tyranny and similar to the freedom." That's why; most jurisdictions have formalized the judicial proceedings. In addition, legal historians have obviously recognized this fact that the patterns of such rules are closely related to the roots of the laws in civil law countries in comparison to the common law states. These legal families are rooted in roman and English law and are transferred to other states through colonialism and capture. (by France, Germany, Spain in civil law and England in Common law)

However the legal systems in most countries are completed after the colonialism, but the key features and the legal roots are often maintained by these states. There are many theories on how the legal root has formulated the civil procedure in general and formalism in particular. Hayek (1960) and Merryman (1985) have attributed these differences to the illuminative ideas and the French revolution. In France the revolutionists and napoleon did not trust the judges, and codified the judicial procedure to control the judicial authorities. According to ....... (1988) in civil law countries the procedure techniques in laws fundamentally mean the public demand from the judicial power and the means to prevent tyranny. In accordance with vongherine logic, the procedural formalism is regarded as a guarantee to the freedom. But in England and the united states of America, the lawyers and judges have sided with the revolutions, and therefore a substitute political process led to a great success in order to achieve the judicial independence. Since the french civil law has paid more attention to the judges (the Napoleon Act), thus it has emohasized greatly on judicial formalism compared to Germany. 


\section{The local jurisdiction}

In the united states of America determining the suitable court does not depend on the abstract concepts, rather it is often needed to perform a conclusive research in this regard to specify if there is a relationship between the court and the defendant and cause of the claim in a specific case. The competence standard is often related to the sufficient relationships or reasonableness of the forum and according to the traditional concept of fair play and justice in order to allow the government to fulfill its obligations, so in the U.S.A the competence beyond the defendant, doesn't have a specific standard, rather the power structure has been personal in order to being reviewed in accordance with each case's needs and considering the specific facts framework of the case. An American lawyer, when modulates a contract, does not know what competence would arise out of such contract. In contrast, a European lawyer always bears in mind the specific laws of a country, where the contract considers a specific court or law. Regarding the common law position towards this issue we might refer to the principle of the unsuitable court. This principle provides: "perhaps a court which is competent to a case, does not accept to hear it, due to this fact that it presumes another court in another district is competent too and could bear justice. This principle is unknown in civil law countries.

Scotland was the first country that developed this concept (unsuitable court) and now kebeque and Louisiana have accepted this principle. Lord Goff of Chievely from the House of Lords suggests that: the principle of unsuitable court has developed such that could be accepted all over the common law world. In fact as this principle is based upon maintaining its competence through the independence of competences which could be considered as one of the most trustworthy legal principles. That's why it is suggested that the researcher usually pay attention to a reporting source.

Description on the difficulty of the relationship between American and European laws about the competence, either at the federal courts or at the states level or regarding recognizing and implementing the decisions of foreign courts, could reveal the fundamental differences between these two systems. The European supervisors believe that the U.S federal courts are sufficient to determine the competence by answering the question that do the defendants are in fact related to the country where the court has been seated.

Regarding the competence, the American law is described through mentioning this historical fact that initially the physical presence of individuals and objects is considered to apply the courts' judicial power. In order to change the conditions and method that is completely useful for the plaintiff, he could litigate against the defendants who have the least relationship with a court's competence, providing that it does not violate the legal formalities necessary for the American constitutional law and reforms. According to the fair and reasonable standard which is considered for the competence, if the court decides that another court is more competent to deal with the case, could refuse the competence. On the contrary, in Europe generally the courts' competence is either based on the jurisdiction where defendant is seated (general competence) or in specific circumstances is based upon other communications between the cause of the claim and the court's jurisdiction (specific competence).

Regarding the competence, civil law has adopted the roman idea on the restricted competence which reflects a fair spirit. This fact that plaintiff is functions under the lexfori is a general principle from Justinian command. Generally civil law needs that the plaintiff refers to the court where the defendant is seated and that court could deal with any claim against defendant irrespective of this fact that the cause of the claim has arised somewhere else. In addition, there are some other regulations concerning the competence in the claims on responsibility and ownership. For instance the plaintiff could litigate in the context of responsibility at any place which the unlawful act has been happened.

Currently the general principle in France provides that the claim has to be litigated in the jurisdiction where the defendant is seated or where the main firm of the legal person is placed, where there are many defendants in a case the plaintiff is free to choose any of these places. (in Germany there is an specific circumstance)

\section{Conclusion}

The mentioned outlines indicates that the comparative study irrespective of the difficulties is a necessary and inevitable issue in the civil procedure and the efforts in order to recognize the common principles governing the trials and among the civilized nations and defining the solutions and various mechanism in order to ensure the access to the fair function of the hearing and holding the international conferences with various legal systems alongside with the international trade's need to eliminate the obstacles and the states' inclination to join the global village reveals the importance of comparative studies in the civil procedure. On the other hand, making use of the universal experiences and modifying the unsuitable structures in the trials and improving the functions calls for the necessity of the comparative study. In addition, recognizing the advantages and disadvantages of the 
legal systems leads to the ease of lawyers and businessmenwho need to follow their drastic purposes outside the national legal system and in order to succeed, they ought to study the resources in other legal systems. Comparative studies' development is effective in developing the commerce and decreases the obstacles, and also provides new ideas in order to modify the existing structure in order to making them efficient.

\section{References}

Akkas, S. A. (2004). Appiontment of judges: A key issue of judicial Indepence. Bond Law Review.

Andrews, N. (2006). English Civil Procedure: A Synopsis Japan Course Ritsumeikan Law Review.

Apple, J. G. (1995). A primer on the civil - law system. Washington, D.C., Federal Judicial Center.

AronBalas, RataelLaporta, Florencio Lopes-de-Silanes, Andrei Shleiter, the divergence to legal procedures, The National Bureau Of Economic Research, 2008.

Arthur T. von Mehran. (2000). the u.s.legal system: Between the common law and civil law legal traditions. Retrieved from www.cisg.law.pace.edu/cisg/biblio/vonmehren

Ashoori, M., concepts of justice and fairness from the perspective of European Convention on Human Rights, article in the book "Human rights and concepts of equality, fairness and justice" Authors: dr. Mohammad Ashoori, dr. Hussein Basharieh, dr. Seyyed Mohammad Hashemi and Abdul MajidYazdi, under the supervision of dr. Mohammad Ashoori, 2005, Tehran, Tehran University Faculty of law and political Science

Beck T., \& Levine, R. (2006). legaltnstitutions and financia. Maastricht University civil procedure.

Blas, F., \& Hottler, P. (2004). Remarles on the damages provisions in the CISG principles of European contact law (PECL) and UNISROIT principles of International contracts. Retrieved from www.cisg.law.pace.edu/cisg/biblio/blase3

Clermont, K. (2004). French article 14 gurisdicticn, viewed from the unitedstates. Cornell Law Faculty Publications.

David, R. (1999). the great contemporary legal systems, translated by Hussein Safa'i, ezatollah Iraq, Muhammad Ashoori (4th ed.). Tehran, University Publishing Center.

Dodson, S. (2009). comparative convergences in pleading standards. William \& Mary School of Law.

Ferejihn, J., Rosenbluth, F., \& Shipan, C. (2004). comparative Judicial politics. Retrieved from www.oxfordhandbooks.com

Fiorini, A. (2008). the codificaition to private international law in Europe. Electronic Journal of comparative law.

Gottwald, P. (2004). Comparative civil procedure. RitsumeikanUniversity.

Karimi, M. (2010). investigate implementation guarantee resulting from violation of obligations of the in CISG, UNIDRIT, PECL, the countries of the Common Law, Civil Law, and the Law of Iran, MA thesis in private Law, Azad University Naragh, February 2010.

Koskinen, G. (2010). specific performance in GISG and Finish law, electronic library on in transactional commercial contracts and the GISG. Retrieved from www.cisglaw.pace.edu

Langbein, J. H. (1987). comparative civil procedure and style of complex contracts. Retrieved from http://digitalcommons.law.yale.edu/fss_papers/537

Lecce, G. (2009). office of Democracy and GoveranceBareau For Democray. Conflict, and Humanitarian Assistance u.S Agency for International Development. Washington, Dc. Dcha U.S. Foregin Assistance Performance Publication FY.

Lee, A. (2004). legal traditions and compettionpolicy. The Quarterly Review of Economics and Finance.

Levine, R. (205). law, Endowments, and property rights. Journal of Economic Perspectives.

Loiccadiet. (2010). Introduction to French ciril justice system and civil procedural law. Ritsumeikan Law Review.

Maute, J. L. (2006). English reforms to judicial selction: comparative lessons fore American states? Fordham Urban Law Journal.

Maxeiner, J. R. (2010). pleading and Access to civil procedure: Historical andcomparative reflections on Iqbol, A day in court and decision according to law, University of Baltimore School of Law Legal Studies Research 
Paper

Mmktin Elizabeth, Oxford dictionary ot low, first scan, winter 1383 Tehran.

Mohseni, H. (2007). civil justice systems. Journal of Law, Faculty of Law and Political Sciences, 1386, Vol. 37, Issue1, Spring.

Mohseni, H., \& Pourtahmasebi Fard, M. (2005). the principle of control of the parties on the grounds and subject of dispute. Journal of Central Bar Association, New Era, (21).

Pablocortes. (2009). An analysis of offers to settlein in common law courts: Are they relevant in the civil law context? University of Leicester - School of Law.

Papaioannou, E. (2011). The Injustice of the Justice System. Dartmouth College, Harvard University.

Parker, J. S. (2008). comparative civil procedure and transnational Harmonization: A law - and - e economics perspective. George Mason University Law and Economics Research Paper.

Popkin, M. (2002). Guidance for promoting judicial independence and Impartiality. United States Agency for International Development, Inprol.

Posner, R. (2009). Inappropriate fourm or inappropriate law? A choice - of - law solution to The jurisdictional standoff between the united states and latin American. Emory Law Journal.

Rafaellaporta, D. (2003). florenicolopez- de-silanes, andyishleifer, The new comparative economics. Journal of Comparative Economics.

Rose, M., \& Burt, G. D. (2008). comparative law: a comprehensive research guide. Florida Coustal School of Law.

Sanstein, C. (1999). Must Formalism Be Defended Empirically? University of Chicago Law School.

Smelser, N. (2001). Encuclopedia of the social \& Behavioral. Social \& Behavioral Sciences.

Spamann, H. (2009). legal origin, civil Procedure, and the Quality of contract enforcement, Discussion Paper No. Harvard Law School.

van Rhee, G. H., \& Verkerk, R. (n.d.). researcher, civil procedure, Elgar Encyclopedia of Comparative law 200.

William Tetley, Q. C. (2003). mixed jurisdictions: common law v.s civil law codified and vncoditied. Retrieved from www.cisg.law.pace.edu/cisg/biblio/tetley

Zuckerman, A. A. S. (1996). Lord Woolfs Accsecc to Justic: PluscaCa Change. Modern Law Review. http://dx.doi.org/10.1111/j.1468-2230.1996.tb02694.x

\section{Copyrights}

Copyright for this article is retained by the author(s), with first publication rights granted to the journal.

This is an open-access article distributed under the terms and conditions of the Creative Commons Attribution license (http://creativecommons.org/licenses/by/3.0/). 